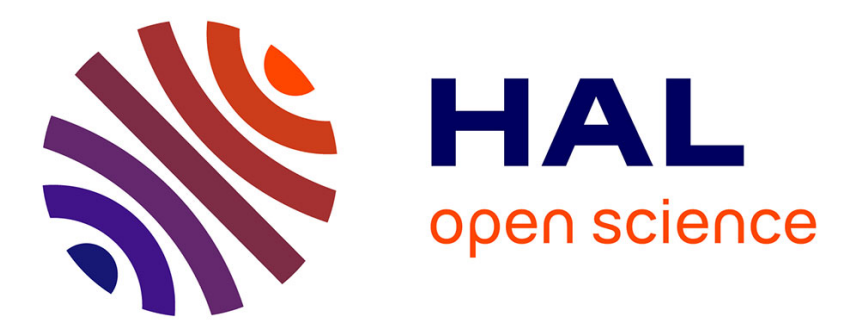

\title{
Disabling ocular sequelae of epidermal necrolysis: risk factors during the acute phase and associated sequelae
} C. Hajj, K. Ezzedine, D. Thorel, A. Delcampe, G. Royer, C. Hua, A. Colin, N de Prost, M. Muraine, O. Chosidow, et al.

\section{- To cite this version:}

C. Hajj, K. Ezzedine, D. Thorel, A. Delcampe, G. Royer, et al.. Disabling ocular sequelae of epidermal necrolysis: risk factors during the acute phase and associated sequelae. British Journal of Dermatology, 2019, 181 (2), pp.421-422. 10.1111/bjd.18023 . hal-02316552

HAL Id: hal-02316552

https://hal-normandie-univ.archives-ouvertes.fr/hal-02316552

Submitted on 16 Oct 2019

HAL is a multi-disciplinary open access archive for the deposit and dissemination of scientific research documents, whether they are published or not. The documents may come from teaching and research institutions in France or abroad, or from public or private research centers.
L'archive ouverte pluridisciplinaire HAL, est destinée au dépôt et à la diffusion de documents scientifiques de niveau recherche, publiés ou non, émanant des établissements d'enseignement et de recherche français ou étrangers, des laboratoires publics ou privés. 
DR CARLA HAJJ (Orcid ID : 0000-0002-8954-499X)

DR KHALED EZZEDINE (Orcid ID : 0000-0002-5468-4589)

DR NICOLAS DE PROST (Orcid ID : 0000-0002-4833-4320)

DR JULIE GUEUDRY (Orcid ID : 0000-0002-8592-3810)

DR SASKIA INGEN-HOUSZ-ORO (Orcid ID : 0000-0002-5383-7096)

Article type : Research Letter

\title{
Disabling ocular sequelae of epidermal necrolysis: risk factors at the acute phase and associated sequelae
}

\author{
C. Hajj ${ }^{1}$, K. Ezzedine ${ }^{1}$, D. Thorel ${ }^{2}$, A. Delcampe ${ }^{2,5}$, G. Royer $^{3,5}$, C. Hua ${ }^{1}$, A. Colin ${ }^{1,5}$, N. de Prost ${ }^{4,5}$, M. \\ Muraine $^{2,5}$, O. Chosidow ${ }^{1,5}$, P. Wolkenstein ${ }^{1,5}$, J. Gueudry ${ }^{2,5}$, S. Ingen-Housz-Oro ${ }^{1,5}$
}

1. Department of Dermatology, AP-HP, Hôpital Henri Mondor, Créteil, France

2. Department of Ophthalmology, CHU Charles Nicolle, Rouen, France

3. Department of Ophthalmology, AP-HP Hôpital Henri Mondor, Créteil France

4. Intensive Care Unit, AP-HP, Hôpital Henri Mondor, Créteil, France

5. National Reference Center for Toxic Bullous Dermatoses, AP-HP, Hôpital Henri Mondor, Créteil, France

Corresponding author: Dr. Saskia Ingen-Housz-Oro, MD

E-mail: saskia.oro@aphp.fr

This article has been accepted for publication and undergone full peer review but has not been through the copyediting, typesetting, pagination and proofreading process, which may lead to differences between this version and the Version of Record. Please cite this article as doi: $10.1111 /$ bjd. 18023

This article is protected by copyright. All rights reserved. 


\section{Funding: none}

\section{Conflicts of interest: none}

Keywords: Eye, Scleral lenses, toxic epidermal necrolysis, Stevens-Johnson syndrome, Sequelae,

Epidermal necrolysis (EN), including Stevens-Johnson syndrome (SJS) (detachment involving <10\% body surface area [BSA]), toxic epidermal necrolysis (TEN, $\geq 30 \%$ BSA), and overlap syndrome (10$29 \%$ BSA) is characterized by a widespread apoptotic destruction of the epidermis and mucous membranes. ${ }^{1}$ Ocular involvement is observed in $75 \%$ of patients at the acute phase. ${ }^{2}$ Severity may be classified according to Power's criteria (mild, moderate or severe involvement). ${ }^{3}$ Ocular sequelae (OS) may result in permanent visual impairment and require prolonged follow-up. ${ }^{4}$

Scleral lenses (SLs) are large-diameter gas-permeable contact lenses designed to cover the corneal surface and protect the cornea against tear evaporation and mechanical trauma of the pathological eyelids while improving visual acuity. SLs have been found effective in improving the comfort of patients with the most disabling OS (marked dryness, symblepharons, persistent inflammation or loss of visual acuity). ${ }^{5}$

This study aimed to determine the risk factors for disabling OS and to identify associated sequelae.

We retrospectively included all EN patients admitted to our reference center at the acute phase between 2005 and 2017 and followed for at least 6 months. The diagnosis was according to previously published clinical and histological criteria. ${ }^{1} \mathrm{We}$ defined disabling OS by the need to wear SLs. Indeed, in our routine practice, according to the dermatologist's and local ophthalmologist's decision, patients considered to have the most disabling OS were referred to the same ophthalmologist expert in the field of EN (AD) for SLs. We collected the following data from medical charts: 1) data on the acute phase: age, sex, Fitzpatrick skin type (I-IV vs V-VI), maximal skin detachment, highest SCORTEN ${ }^{6}$ during the first 5 days, number of mucous membranes affected $(\leq$ or $>3)$, transfer to an intensive care unit, initial ocular involvement according to Power's criteria ${ }^{3}$ and 2) associated sequelae: cutaneous, nail, and psychiatric sequelae during follow-up.

This article is protected by copyright. All rights reserved. 
Demographic and clinical characteristics were expressed as mean (SD) or number (\%). Differences between patients with and without SLs were investigated by univariate logistic regression, estimating odds ratios (ORs) and 95\% confidence intervals (CIs). The OR significance was determined by Wald, chi-square or Fisher's exact test as appropriate, with $\mathrm{P}<.05$ considered statistically significant. Patients gave consent for the use of anonymized data and the database was declared to the Commission Nationale Informatique et Libertés (no. 20190327153039).

Among 205 consecutive patients referred during the study period, 177 (99 females; mean [SD] age 46 [20] years) were included; 26 (15\%) had an indication for SLs and were compared to 151 without SLs (Table). The median time between the acute phase and the first SL consultation ( $\mathrm{n}=20)$ was 1 year $(6$ months-6 years).

During the acute phase, the following were higher or more frequent in patients with than without SLs: mean [SD] BSA involved (39\% [28\%] vs 21\% [22\%], p = .0009), mean SCORTEN (2.19 [1] vs 1.58 [1], $\mathrm{p}=.011$ ), extensive mucosal involvement (58\% vs 35\%, $\mathrm{p}=.03$ ), and severe Power stage (77\% vs $9 \%, \mathrm{p}<.0001)$. However, we found no association between OS and sex, age, Fitzpatrick skin type, transfer to an intensive care unit or treatment with cyclosporine.

Similarly, during follow-up, nail sequelae were more frequent in patients with than without SLs (54\% vs $24 \%, \mathrm{p}=.002$ ), as were psychiatric disorders ( $58 \%$ vs $25 \%, \mathrm{p}=.001$ ). We found no association between $\mathrm{OS}$ and pigmentation sequelae.

Overall, $15 \%$ of our patients warranted SLs. At the acute phase, EN was more severe with than without SLs: higher percentage of detached skin, more extensive mucosal involvement, higher SCORTEN, and more severe eye damage. In our study, phototype was not associated with increased risk of development of disabling OS. However, we recently showed that among patients requiring SLs, Fitzpatrick skin type V-VI was associated with more severe ophthalmological involvement (loss of visual acuity, symblepharons, trichiasis, corneal ulcerations). ${ }^{7}$ Thus, rigorous ophthalmologic care is needed at the acute disease phase, but consensual guidelines are lacking. ${ }^{4}$ Encouraging preliminary results have been obtained for amniotic membrane transplantation. ${ }^{8}$

This article is protected by copyright. All rights reserved. 
Our study emphasizes the significant association between disabling OS and other sequelae that impair quality of life (nail and psychiatric sequelae).

The limitations of our study include a probable underestimation of the number of patients requiring SL because not all patents were necessarily referred to the specialized consultation. As well, details on the severity of psychiatric sequelae were lacking because of the retrospective design.

The initial disease severity is the main risk factor for disabling OS. Initial close ophthalmologic screening and follow-up is warranted. Consensus is needed for the best ophthalmological treatment at the acute phase.

This article is protected by copyright. All rights reserved. 


\section{References}

1. Duong TA, Valeyrie-Allanore L, Wolkenstein P, Chosidow O. Severe cutaneous adverse reactions to drugs. Lancet. 2017;390:1996-2011.

2. Gueudry J, Roujeau JC, Binaghi M, Soubrane G, Muraine M. Risk factors for the development of ocular complications of Stevens-Johnson syndrome and toxic epidermal necrolysis. Arch Dermatol 2009;145:157-62.

3. Power WJ, Ghoraishi M, Merayo-L, loves J, Neves RA, Foster CS. Analysis of the acute ophthalmic manifestations of the erythema multiforme/Stevens-Johnson syndrome/toxic epidermal necrolysis disease spectrum. Ophthalmology. 1995;102:1669-1676.

4. Ingen-Housz-Oro S, Duong TA, Bensaid B et al. Epidermal necrolysis French national diagnosis and care protocol (PNDS; protocole national de diagnostic et de soins). Orphanet J Rare Dis. 2018;13:56. doi:10.1186/s13023-018-0793-7.

5. Tougeron-Brousseau B, Delcampe A, Gueudry $\mathbf{J}$ et al. Vision-related function after scleral lens fitting in ocular complications of Stevens-Johnson syndrome and toxic epidermal necrolysis. Am J Ophthalmol. 2009;148:852-9.

6. Guégan S, Bastuji-Garin S, Poszepczynska-Guigné E, Roujeau JC, Revuz J. Performance of the SCORTEN during the first five days of hospitalization to predict the prognosis of epidermal necrolysis. J Invest Dermatol. 2006 Feb;126(2):272-6.

7. D. Thorel, A. Delcampe, S. Ingen-Housz-Oro et al. Skin phototype may be a risk foctor for ocular complications of Stevens-Johnson and toxic epidermal necrolysis. $\mathrm{Br} J$ Dermatol. 2019 Jan 11. doi: 10.1111/bjd.17627

8. Kobayashi A, Yoshita T, Sugiyama K et al. Amniotic membrane transplantation in acute phase of toxic epidermal necrolysis with severe corneal involvement. Ophthalmology. 2006;113:126-132.

This article is protected by copyright. All rights reserved. 
Table: Comparison of risk factors at the acute phase of epidermal necrolysis and associated sequelae between patients with and without scleral lenses.

\begin{tabular}{|c|c|c|c|c|c|}
\hline Variables & $\begin{array}{l}\text { Total } \\
\mathbf{n}=177\end{array}$ & $\begin{array}{l}\text { Scleral lenses } \\
\mathrm{n}=26\end{array}$ & $\begin{array}{l}\text { No scleral lenses } \\
\mathbf{n}=\mathbf{1 5 1}\end{array}$ & OR $[95 \% \mathrm{CI}]$ & p-value \\
\hline \multicolumn{6}{|l|}{ Demographic characteristics } \\
\hline Female sex, n (\%) & $99(56)$ & $18(69)$ & $81(54)$ & $1.94[0.79-4.78]$ & .14 \\
\hline Age, mean (SD) & $92(52)$ & $46(20)$ & $46(19)$ & $1[0.98-1.02]$ & .99 \\
\hline Phototype V-VI, n (\%) & $61(34)$ & $10(38)$ & $51(34)$ & $1.23[0.52-2.90]$ & .64 \\
\hline Stevens-Johnson syndrome, $\mathrm{n}(\%)$ & $61(34)$ & $4(15)$ & $57(38)$ & \multirow[t]{2}{*}{$3.34[1.07-10.37]$} & \multirow[t]{2}{*}{.03} \\
\hline Overlap syndrome or toxic epidermal necrolysis, $\mathrm{n}(\%)$ & $116(66)$ & $22(85)$ & $94(62)$ & & \\
\hline Maximum skin detachment (BSA), mean (SD) & $28 \%(27)$ & $39 \%(28)$ & $21 \%(22)$ & $1.02[1.01-1.04]$ & .0009 \\
\hline Maximum SCORTEN, mean (SD) & $1.86(1.24)$ & $2.19(1)$ & $1.58(1)$ & $1.67[1.12-2.47]$ & .011 \\
\hline Number of affected mucous membranes $>3, \mathrm{n}(\%)$ & $68(38)$ & $15(58)$ & $53(35)$ & $2.52[1.07-5.96]$ & .03 \\
\hline \multicolumn{6}{|l|}{$\begin{array}{l}\text { Initial ocular involvement according Power criteria*, } \mathrm{n} \\
(\%)\end{array}$} \\
\hline No or mild involvement & $81(46)$ & $2(8)^{\$}$ & $110(73)$ & $68.1[9.76-733.51]$ & $<.0001$ \\
\hline Moderate involvement & $32(18)$ & $4(15)^{\$ \$}$ & $28(19)$ & & \\
\hline Severe involvement & $33(19)$ & $20(77)^{\$ \$ \$}$ & $13(9)$ & & \\
\hline Transfer to ICU, n (\%) & $36(20)$ & $7(27)$ & $29(19)$ & $1.54[0.59-4.05]$ & .37 \\
\hline Treatment with cyclosporine, $\mathrm{n}(\%)^{* *}$ & $69(40)$ & $13(50)$ & $56(38)$ & $1.60[0.64-4.05]$ & .26 \\
\hline
\end{tabular}

BSA, body surface area; SCORTEN, severity-of-illness score for TEN; ICU, intensive care unit; * Power criteria: mild involvement (eyelid edema, and/or mild conjunctival injection, and/or chemosis only), moderate involvement (membranous conjunctivitis, and/or corneal epithelial defects, more than 30\% healing with medical treatment, and/or corneal ulceration, and/or corneal infiltrates ) or severe involvement (symblepharon formation, and/or nonhealing corneal epithelial defects, and/or visual loss, and/or conjunctival fornix foreshortening); **missing data $n=5$; \$ mild conjunctival injection; ${ }^{\$ \$}$ : corneal ulceration; ${ }^{\$ \$}$ : symblepharon formation $(n=18)$ and non-healing corneal epithelial defects $(n=2)$

This article is protected by copyright. All rights reserved. 